Systematic Review

\title{
Evidence on the Relationship between Place Attachment and Behavioral Intentions between 2010 and 2021: A Systematic Literature Review
}

\author{
Lisa Dang ${ }^{1, *(\mathbb{C} \text { and Jan Weiss }}{ }^{2}$ \\ 1 Institute of Tourism and Mobility ITM-The Mobility Competence Centre, Lucerne University of Applied \\ Sciences and Arts, 6002 Lucerne, Switzerland \\ 2 Risk Analytics and Regulatory Banking, Sopra Steria Next, 22085 Hamburg, Germany; \\ jan.weiss@soprasteria.com \\ * Correspondence: lisa.dang@hslu.ch
}

Citation: Dang, L.; Weiss, J. Evidence on the Relationship between Place

Attachment and Behavioral

Intentions between 2010 and 2021:

A Systematic Literature Review.

Sustainability 2021, 13, 13138. https:/ /

doi.org/10.3390/su132313138

Academic Editors: Irene Petruccelli and Giulio D’Urso

Received: 18 October 2021

Accepted: 24 November 2021

Published: 27 November 2021

Publisher's Note: MDPI stays neutral with regard to jurisdictional claims in published maps and institutional affiliations.

Copyright: (c) 2021 by the authors. Licensee MDPI, Basel, Switzerland. This article is an open access article distributed under the terms and conditions of the Creative Commons Attribution (CC BY) license (https:/ / creativecommons.org/licenses/by/ $4.0 /)$.

\begin{abstract}
Place attachment is a key concept in understanding affective person-place relationships, and it provides an appropriate approach for the study of human behavior. This systematic literature review based on the PRISMA guidelines focuses on the relationships between place attachment and behavioral intentions. Due to the high number of studies that used place attachment as an independent or mediating variable, we categorized the studies into different research areas, which include business and management, risk and crisis, urban planning, environmental psychology, leisure, and hospitality and tourism. The results of the qualitative analysis revealed that most of the studies provided empirical evidence of a significant relationship between place attachment and willingness to pay, loyalty, risk coping behavior, land management practices, civic engagement, proenvironmental behaviors, and pro-tourism behaviors such as revisit and recommendation intentions. After we present our results and conclusion, we provide an outlook on the need for further research.
\end{abstract}

Keywords: place attachment; behavioral intentions; management; crisis; urban planning; environmental psychology; leisure; tourism

\section{Introduction}

The concept of place attachment has been studied in a variety of scientific disciplines, including environmental psychology, human geography, and sociology [1], over the past few decades. While it began the research field of psychology, the concept has now also been established in other research fields, such as tourism [2], crisis management [3], and business [4]. Depending on the research direction, different-and sometimes overlappingterminologies are often used in this context. As a result, several definitions have emerged over the past decades, which can make a basic comparison difficult [5-7]. Reference [8], for example, point out that terms, such as community attachment, sense of community, place attachment, place identity, place dependence, or sense of place, are used to describe place attachment. However, behind each term lies a different meaning, even if the meanings are not easy to differentiate and the concepts partly overlap [9]. Common to all definitions is that place attachment refers to the relationship between individuals and their environment. Most definitions emphasize the emotional aspect that is associated with a specific place [9-11]. In many cases, these are positive emotions such as familiarity, orientation, and security. The term place attachment was primarily coined in the context of environmental psychology. Studies in this research area analyze the extent to which an individual's attachment to a place promotes environmentally conscious behavior [12] Since the 1980s, the term has increasingly appeared in the environmental literature in reference to neighborhoods, and since the 1990s, the focus of its use has been on the affective aspects between people and their environment [11]. Place attachment is considered a key concept for capturing affective person-place relationships [13] and it provides an 
appropriate approach for the study of human behavior [14]. It is therefore valuable for researchers to follow the evolution of this psychological construct and gain new insight into its effects with and on specific behaviors. Systematic literature reviews can provide an overview of existing studies by presenting existing findings ("what is already done and what is known") to other researchers in a concise but content-rich manner [15].

Two literature reviews have already been performed on the topic of place attachment. Reference [5] examined the development of the concept over the previous 40 years. Reference [2] published the most recent literature review on place attachment, which analyzes the concept in the context of sustainable tourism, destination competitiveness, and tourism resilience. The aim of the present systematic literature review is to examine developments in the area over the past 10 years (i.e., from 2010 to mid-2021) without a particular focus on one research field, but rather to provide a general overview across all disciplines. Since much of the existing research takes up the psychological concept of place attachment to explain behavioral intentions of individuals or explains the development of place attachment with a particular behavioral intention, this paper examines these associations. While the goal of qualitative studies is to dig deep into a topic and obtain information about respondents' motivations, thinking, and attitudes, quantitative data are used to make social phenomena measurable and evaluate them statistically. Since studies that measure statistical dependencies between place attachment and behavioral intentions have more precise data to provide a general overview, we chose to only include quantitative studies focusing on place attachment and behavioral intention.

The structure of the paper is as follows. First, we describe the methodology of this systematic literature review, which is based on the PRISMA guidelines. We present the results of the qualitative analysis in the main body of the paper. The results are divided into the operationalization of place attachment, place attachment as an independent or mediating variable, place attachment as a moderator variable, and place attachment as a dependent variable. Due to the high number of studies using place attachment as an independent or mediating variable, this section is also categorized into different research areas (i.e., business and management, risk and crisis, urban planning, environmental psychology, leisure, and hospitality and tourism). Finally, we present our conclusion, as well as an outlook on the need for further research.

\section{Materials and Methods}

We conducted the literature search on 23 July 2021. We used two databases for the systematic literature review, Web of Science and ProQuest, and we applied the following search criteria:

1. The term "place attachment" must be mentioned in the title.

2. The term "intention" must be mentioned in the abstract.

3. The year of publication must be between 2010 and 2021 .

This search query led to 77 results from Web of Science and 60 results from ProQuest. Thus, we identified a total of 137 references. From these, 49 duplicate results were eliminated, leaving 88 results. The screening of studies was performed by both authors. We determined that only peer-reviewed journal articles should be included in the qualitative analysis to ensure the quality of the included scientific publications. Accordingly, all other literature articles, such as university theses, dissertations, working and conference papers, or books, were screened out. After these were screened out, 77 results remained. The full text of each of these results was reviewed for qualification. Since we only included quantitative studies with a behavioral intention in the analysis, we also removed one study without a behavioral intention variable, three cluster analyses, four qualitative studies, one review, and two conceptual papers from the analysis. Ultimately, we included 66 results from the literature search into the analysis. Figure 1 illustrates the PRISMA 2020 flow diagram (based on [16]).

An Excel spreadsheet was created for the 66 studies included in the qualitative analysis. For each study, the method, measurement of place attachment, key results, implications, 
and further research needs were documented. Based on this table, the findings were synthesized and compared by both authors.

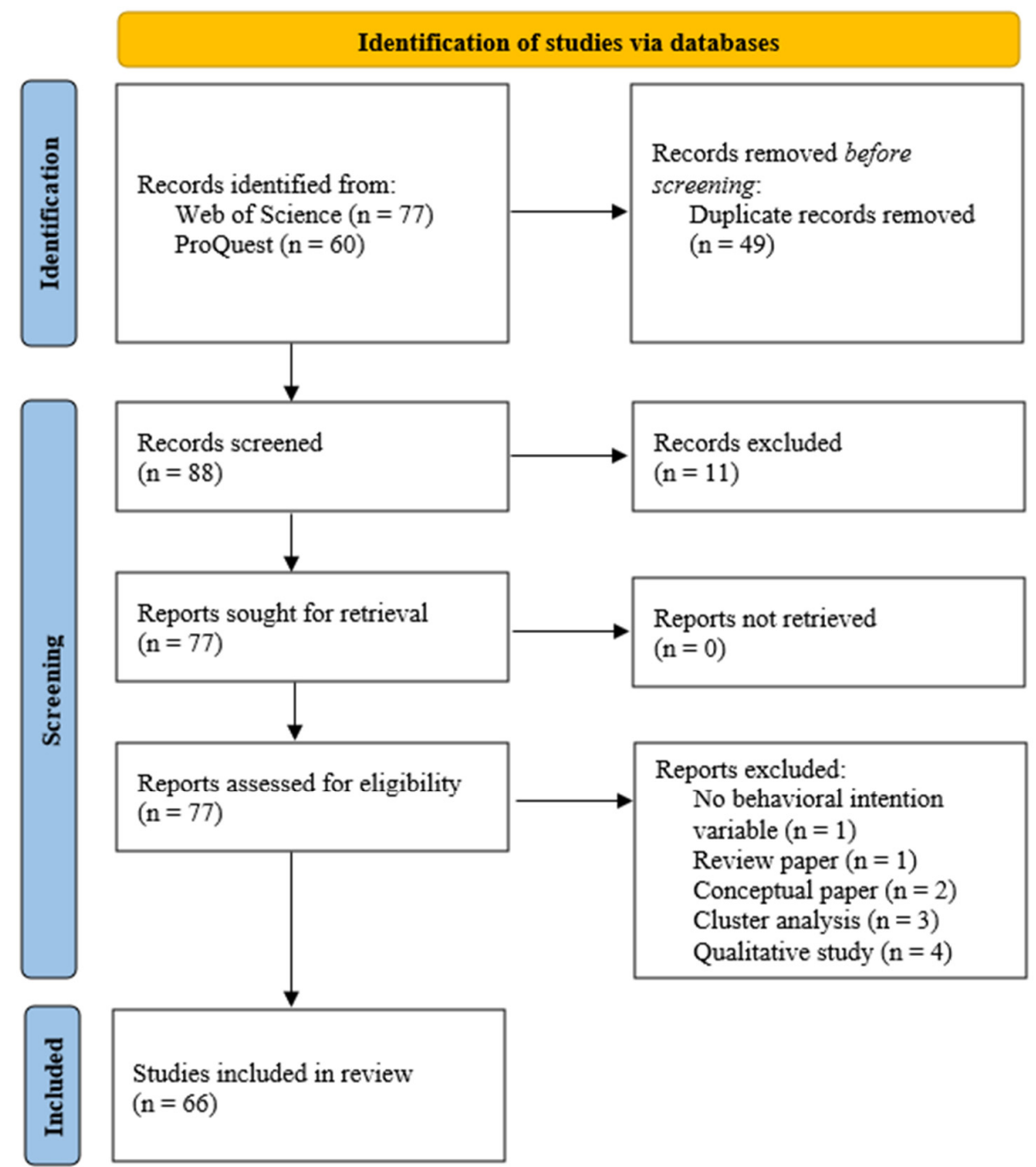

Figure 1. PRISMA 2020 flow diagram; (Source: own illustration based on [16]).

\section{Results}

\subsection{Operationalization}

There is no clear consensus in the literature on how place attachment should be measured $[6,7]$. Therefore, this literature review provides an overview of the operationalization of place attachment in the studies considered.

Table 1 demonstrates that place attachment is predominantly measured one-dimensionally (19 studies) or two-dimensionally, with place identity and place dependence as subdimensions (23 studies). One-dimensional measurements of place attachment are particularly based on the work of References [17-20]. The measurement of place attachment using place identity and place dependence is predominantly based on the work of References [20-26].

Further prominent in the literature is the measurement of place attachment via the dimensions of place identity, place dependence, and either place effect (six studies) or place social bonding (two studies). In some cases, the latter is modified. For example, some studies make a distinction between social bonds between employees and customers [27] or between family bonding and friend bonding [28]. Nature bonding is also occasionally included $[28,29]$.

Some of the studies (eight studies) relied on all four of the mentioned dimensions: place dependence, place identity, place affect, and place social bonding. The remaining studies considered in this literature review refer to similar yet unique dimensions. For 
example, Reference [30] measured place attachment with place dependence, place affect, place identity, and place symbolism rather than place social bonding, while Reference [31] drew on place satisfaction. This is contrary to the assertions of other authors who consider place satisfaction to be a result of place attachment (see, e.g., [19,30]). Reference [32] distinguished between evaluative and interactive place attachment when measuring place attachment. Evaluative place attachment is measured with the usual four dimensions, while interactive place attachment includes place memory and place expectation. In addition, Reference [33] measured place attachment with functional and cognitive attachment, while Reference [4] used social awareness, location awareness, and task awareness.

Table 1. Operationalization of place attachment in the included studies $(n=66)$; (Source: own illustration).

\begin{tabular}{cc}
\hline Operationalization & Authors \\
\hline & {$[7]$} \\
& {$[34]$} \\
& {$[35]$} \\
& {$[3]$} \\
& {$[36]$} \\
Unidimensional & {$[37]$} \\
(19 studies) & {$[38]$} \\
& {$[39]$} \\
& {$[40]$} \\
& {$[41]$} \\
& {$[42]$} \\
& {$[43]$} \\
& {$[44]$} \\
& {$[45]$} \\
{$[46]$} \\
& {$[47]$} \\
& {$[48]$} \\
& {$[49]$} \\
& {$[50]$} \\
\hline & {$[51]$} \\
& {$[52]$} \\
& {$[53]$} \\
& {$[54]$} \\
& {$[55]$} \\
& {$[56]$} \\
& {$[57]$} \\
& {$[58]$} \\
& {$[59]$} \\
& {$[60]$} \\
& {$[61]$} \\
& {$[62]$} \\
& {$[63]$} \\
& {$[64]$} \\
& {$[65]$} \\
& {$[66]$} \\
& {$[67]$} \\
& {$[68]$} \\
& {$[69]$} \\
& {$[70]$} \\
& {$[71]$} \\
& {$[72]$} \\
& {$[73]$} \\
\hline &
\end{tabular}


Table 1. Cont.

\begin{tabular}{cc}
\hline Operationalization & Authors \\
\hline & {$[74]$} \\
Place identity, place dependence, place affect & {$[75]$} \\
(six studies) & {$[76]$} \\
& {$[77]$} \\
Place functions / features (place dependence), place emotion/identity, and & {$[78]$} \\
social bonding & {$[79]$} \\
\hline Place identity, place dependence, social bonds with employees, and social & {$[80]$} \\
bonds with customers & {$[81]$} \\
\hline Place identity, place dependence, nature bonding, and social bonding & {$[27]$} \\
\hline Place dependence, place identity, family bonding, friend bonding/ties, and & {$[29]$} \\
nature bonding & {$[28]$} \\
\hline & {$[82]$} \\
\hline Flace dependence, place identity, place affect, and place social bonding & {$[83]$} \\
\hline (eight studies) & {$[84]$} \\
\hline Place dependence, place affect, social bonding, and place satisfaction & {$[10]$} \\
\hline & {$[85]$} \\
\hline & {$[86]$} \\
\hline & {$[87]$} \\
\hline
\end{tabular}

\subsection{Place Attachment as an Independent Variable}

Most of the studies included in this review use place attachment to explain a specific behavioral intention $(n=56)$ rather than considering place attachment as a moderating $(n=6)$ or dependent variable $(n=4)$. To provide a better overview, the studies were first categorized in terms of their research discipline by both authors. This allowed us to identify the following topics: business and management, risk and crisis, urban planning, environmental psychology, leisure (including sports and festivals), and hospitality and tourism. The topics were identified by categorizing the included studies according to their keywords in the title and abstract. The research findings and their implications are presented below.

\subsubsection{Business and Management}

Studies in the business and management topic focus on areas that are actively managed by companies to increase their profits. In this case, these include advertising, brand management, and customers' loyalty and willingness to pay.

Three studies from the literature search can be assigned to the research area of business and management. Two of these focused on the connection between place attachment and online brand engagement. They found that place attachment has a positive influence on the online distribution of place brand advertising materials [7] and on participation in online brand communities [4]. The mediators between these relationships were place ad-brand congruity and self-expressiveness [7] as well as service experience and brand 
engagement [4]. Based on these results, it is recommended that brand managers include location-based cues in advertising [4]. These should relate to social, functional, and cultural aspects and, as far as possible, represent that with which local residents identify [7]. This approach could ensure that the positive effects of place attachment can be used to enhance intentions to promote the place as a brand online.

Another study by Reference [75] analyzed place attachment to explain customers' loyalty to natural areas such as parks as well as their willingness to pay. They found that both affective (place affect) and functional (place dependence) components played important roles in increasing willingness to pay and loyalty. For park managers, this means that they should be aware of the wishes and needs of their target group in order to adapt their offers accordingly [75].

\subsubsection{Risk and Crisis}

This topic focuses on studies that deal with risk perception and risk coping behavior, for example, in connection with the occurrence of environmental disasters.

We found that research in the area of risk and crisis dealt mainly with place attachment in the context of risk perception. During the period relevant to this paper, three studies were performed on this topic. Reference [3] showed that place attachment has a negative influence on risk perception, as residents of a place see the associated risk as a part of that place. In addition, individuals with higher place attachment showed lower intentions to move away from that place and higher intentions to protest against facilities that could have harmful effects on the place and on the people in that place [28]. While in the study by Reference [3], place attachment was shown to have a negative influence on risk perception, Reference [28] indicated that higher place attachment has a negative moderation effect on the positive relationship between risk perception and the intention to move away. Both studies revealed that attachment to a place and the social ties associated with it can lead to a lower perception of the risks of the place and to lower intentions to move away. This is often referred to as risk perception normalization [88]. In risk perception normalization, individuals perceive the risk associated with a place to be a part of that place; they may also develop strategies to deal with the risk to which they have voluntarily exposed themselves [89,90].

While these two studies investigated attachment to a place of residence, the work of Reference [35] added attachment to the evacuation site. Using both types of place attachment, they aimed to explain the evacuation behavior of individuals who are exposed to natural environmental hazards, such as hurricanes or tsunamis, at their place of residence. While home place attachment was found to have no influence, evacuation site place attachment strengthened the intention to evacuate [35]. This study thus provides further empirical evidence that place attachment does have an influence on risk perception and risk coping behavior.

\subsubsection{Urban Planning}

Urban planning is the generic term for all planning issues within a city. This includes, for example, the behavior of landowners, plans of residents to move in or out, and civic engagement intentions within a community.

Several studies investigated the relationship between place attachment and placeoriented behavioral intentions among landowners. Among the three dimensions of place attachment in the study by Reference [80], place identity was shown to have a positive and significant influence on place intention (i.e., the owner's intention not to sell their land property). The other two dimensions-place functions/features and place social bondinginfluenced intentions to engage in land practices such as maintaining important ecosystem features on the property or protecting native plants [80]. Accordingly, place attachment has been shown to play a special role in the development of place-based behavioral intentions in land management. A more recent study by Reference [36] confirmed these findings. 
They also found that higher place attachment led to both a lower intention to sell land and higher intention to leave a will to bequeath the land to their heirs [36].

Closely related to land management behavioral intentions, two of the studies were devoted to the intention to live in or move away from a particular place. Reference [33] used two variables to measure the intention to move away. These variables are mismatch (i.e., the degree to which individuals' needs are not met in their current place) and opportunities elsewhere (i.e., the opportunities are available to the individual in another place). Their results revealed that higher residential satisfaction leads to higher place attachment, which in turn negatively influences the intention to move away. While functional attachment (i.e., the functional and physical aspects of a place) negatively influences mismatch, cognitive attachment (i.e., experience, perception, and memory of the place) negatively influences both mismatch and opportunities elsewhere. Cognitive attachment relates to place identity, which implies that strong identification with a place through experience, memory, and knowledge will keep the individual from moving away. In fact, it stands to reason that individuals who feel attached to a place are more likely to engage in and help shape the environment according to their own desires. Conversely, place dependence decreases if the place does not fulfill its function-in other words, if it cannot meet the individual's needs. These individuals would then be more willing to give up their current place of residence [33]. Contrary to the work by Reference [33], Reference [37] did not study the current residents of a place; instead, they studied students' intentions to return to their rural home villages after graduation. Among all of the explanatory variables, place attachment was found to be the strongest predictor. This illustrates that the affective component plays a larger role in the decision to return home than objective factors, such as expected income, that were also considered in their study. Based on this, it is recommended that efforts be made to strengthen children's and adolescents' place attachment to their home village during the early years of education. This could be achieved, for example, by strengthening civic engagement among young people. Place attachment can be promoted by teaching social and community values in school and encouraging participation in civic activities [37].

Nevertheless, the direction of the effect between civic engagement and place attachment is not clear. While Reference [37] suggested that involvement in civic engagement activities can lead to higher place attachment, References [38,87] indicated that the relationship is reversed, holding that higher place attachment leads to higher civic engagement and loyalty to a place. Meanwhile, Reference [38] found that intervention (in this case, teaching local history) can lead to higher interest in local history, which in turn has a positive impact on place attachment. These findings are particularly relevant for urban development and for building new cities or neighborhoods. Urban planners should encourage teaching the history of a place to both the local population and to newcomers in order to increase local engagement, which can ultimately help to shape individuals' perceptions of the place [38]. Mutually supportive neighborhoods and functioning social networks can be established if urban planners manage to create high place attachment among residents [87].

\subsubsection{Environmental Psychology}

The topic of environmental psychology examines the influence of human activity and underlying psychological concepts on the environment, e.g., the influence of place attachment on pro-environmental behaviors.

Most of the studies provided empirical evidence of a positive relationship between place attachment and pro-environmental behavioral intentions. References $[6,10,83,84]$ used four subdimensions to measure place attachment: place dependence, place identity, place affect, and place social bonding. However, they obtained different results. The studies by References $[10,84]$ found that place identity, place dependence, and place affect had a positive influence on satisfaction, whereas contrary to expectations, place social bonding had a significant negative effect. Reference [83], on the other hand, found that only place dependence and place identity had a significant positive effect on place satisfaction, which partially mediated the effects on pro-environmental behavioral intentions. In a similar vein, 
Reference [52] confirmed that place attachment has a direct positive influence on conservation intention, on the one hand, and an indirect influence via place satisfaction, on the other hand. Reference [81] measured place attachment as a three-dimensional construct with place identity, place dependence, and social bonding (here called "everybody's happy") to reveal that place identity was the only significant predictor of pro-environmental behavioral intentions. The strength of the effect of place identity became stronger when it was a behavioral intention that required a higher level of commitment [81]. Contrary to the findings of Reference [83], however, References [10,84] found that place identity and place dependence had no significant influence on pro-environmental behavioral intentions. Nevertheless, the studies agreed on the positive influence of place affect on both low-effort and higheffort pro-environmental behavioral intention [10,83,84]. Interestingly, References $[10,84]$ also found that place social bonding positively influenced low-effort pro-environmental behavioral intention but negatively influenced high-effort pro-environmental behavioral intention. Finally, Reference [74] illustrated that the individual dimensions of place attachment may not have a separate influence on behavioral intention, but that place identity did have a positive influence on place dependence, which in turn reinforces pro-environmental behavioral intentions.

Based on the results of these studies, it can be concluded that the dimensions of place attachment do not all show the same effects; this has also been suggested by other authors (e.g., [91,92]). To increase satisfaction, all dimensions of place attachment should be addressed [10]. It would therefore be wise to use local place names and the term "we" to create a common identity in communication measures that aim to increase the commitment of visitors. Marketing efforts should frame visitor collaboration and engagement as part of the place so that visitors who identify with the place perceive collaboration and engagement as part of that identity [81]. Place affect can be strengthened, for example, by designing marketing campaigns that aim to increase repeat visits by helping visitors feel emotionally connected to the place [10]. It is further advisable to involve local communities in the conservation of endangered areas, as they have a higher place attachment than non-local people such as tourists [83]. Providing information to visitors, such as education on the relevance of pro-environmental behaviors, developing social interactions with the local population, or offering tour guides or opportunities to get involved environmentally can help build emotional connection, which can lead visitors to get involved in conservation engagement $[6,10,83]$. When changes are made to a park or a place, care should be taken to ensure that their effects are analyzed or that changes are made in concert with the desires and needs of the visitors; otherwise, visitors' attachment to the place may be destroyed [52].

Other studies focused on moral and social norms related to place attachment. They showed that place attachment has a significant influence on social norms [42], moral norms [29,76], attitude, and awareness of consequences [29]. These mediators have been found to carry over the effect of place attachment to water conservation intention among farmers [76], recycling intentions [29], and climate change adaption strategies [42]. When attitudes, moral norms, and awareness of consequences are compared, the latter has been shown to be the strongest mediator [29]. Moreover, the work of Reference [42] revealed that risk perception, along with place attachment, is a significant positive predictor of social norms. However, they also found place attachment to be a stronger influencing factor than risk perception [42]. These findings strongly suggest that managers should include place attachment as a key concept in their strategy development $[29,42]$. Strengthening place attachment can strengthen attitudes and intentions toward pro-environmental behaviors, moral norms, and awareness of consequences, which can benefit the place's environment [29].

The study by Reference [41] was one of the few that could not prove a significant (mediating) effect of place attachment on pro-environmental behavior (here, "protecting cultural heritage"). An individual's perception of an outstanding universal value of the attraction or place and service quality positively influences place attachment and their intention to protect heritage. However, place attachment and intention were not 
significantly related in this study. The results of this research suggest that place attachment does not always have a positive, significant influence on pro-environmental behavioral intentions [41]. Further research is needed to determine under which conditions place attachment contributes to the formation of pro-environmental behavioral intentions.

\subsubsection{Leisure}

In the leisure category, the focus is on studying events such as sporting events or festivals. The included studies investigate, for example, to what extent visitors' place attachment to an event affects their recommendation and revisit intentions.

Reference [56] drew an arc between environmental psychology and leisure by testing the influence of place attachment of outdoor sports participants on certain pro-environmental behaviors. The authors provided evidence that increasing visitation frequency of outdoor sports participants led to higher place identity and place dependence. Beyond that, however, place identity had no significant effect on the pro-environmental behaviors examined in this study, including the intention to actively engage in environmental protection, the intention to use something or visit somewhere less often so that the place can recover from environmental damage, and the intention to learn about pro-environmental behaviors and environmental protection. Place dependence, on the other hand, was found to have a significant positive influence on the first and third intentions. Furthermore, sports programs conducted outdoors were relevant to strengthening attachment to the place where the sports program was conducted. In addition, educational programs, for example, can help individuals remain informed about the status and importance of environmental protection in the context of the place in question [56].

The other studies in this research field used place attachment to analyze revisit or recommendation intentions. These studies agree that place attachment is a significant predictor of intention to revisit $[30,44,53-55]$ or recommend the event to others $[43,44,54]$. Some of this research also took event satisfaction into account to explain behavioral intentions, revealing that place attachment mediates the effect of satisfaction on intentions. The work of Reference [44] proved that festival satisfaction is positively related to life satisfaction and place attachment, while all three constructs influenced revisit intention and the intention to recommend the event to others. As other studies have demonstrated (e.g., [30,52,55], place attachment was found to be the most significant predictor of intentions [44]. Other authors have confirmed that satisfaction with the attributes of an event positively contributed to place attachment, which in turn increased revisit intention [53] and intention to recommend [43]. Moreover, Reference [43] indicated that festival quality positively influenced festival experiences; good festival experiences led to higher festival satisfaction and the intention to recommend the event to others. Reference [54] considered satisfaction with the co-creation experience to explain festival satisfaction and place attachment. Satisfaction with the co-creation experience refers to satisfaction with customer-customer interactions, especially with regard to the social value and social experiences that visitors experience during their festival stay. These results suggest that satisfaction with co-creation has a positive influence on festival satisfaction and both place attachment dimensions (i.e., place identity and place dependence). However, only festival satisfaction and place dependence were found to determine the intention to visit the festival again or to recommend it to others; in this case, place dependence also mediated the effect of festival satisfaction. In contrast to these studies, which identified event satisfaction as a predictor of place attachment, Reference [30] analyzed the influence of sport involvement and place attachment on event satisfaction and intention to visit the location again. While their results demonstrated that sports involvement and place attachment positively influenced revisit intention, they did not find an effect on satisfaction with the event [30].

Based on these findings, it is recommended to improve event quality standards $[43,53]$. A framework of education, entertainment, escape, and aesthetics could stimulate excellent festival experiences. Festival developers should focus on informing visitors about exciting place-related features (education), providing diverse entertainment programs 
(entertainment) and fun activities (escape), and creating an appropriate, harmonious physical environment (aesthetics) [43]. It is suggested that event planners should align their event attributes, programs, and values according to their target audience. For example, a balanced combination of sleeping, dining, shopping, and diverse programming has been shown to strengthen visitor attachment and encourage them to return [44]. Moreover, activities that bring different festivalgoers together and promote social exchange can be effective in fostering satisfaction with the co-creation experience [54].

\subsubsection{Hospitality and Tourism}

Twenty-six of the studies covered the field of hospitality and tourism. This topic focuses on studies that analyze pro-tourism behavioral intentions, such as participation in tourism development or recommendation and revisit intentions.

This research area is thus the most strongly represented in this paper. All of these studies demonstrated a positive direct or indirect relationship between place attachment and pro-tourism-related behaviors. Pro-tourism behavioral intention refers to behaviors that promote the destination, such as providing information to tourists or protecting resources that are significant for tourism [49].

The research of References [32,72,73] examined residents' support for tourism at the destination. Reference [32] compared the influence of place attachment and place satisfaction on four behavioral intentions: participation in tourism development and planning, word-of-mouth, intention to participate as a representative of the destination (ambassador behavior) (i.e., to externalize the destination's image and values), and intention to leave. Evaluative and interactive place attachment were found to have a significant positive influence on word-of-mouth and ambassador behavior, whereas in both cases, interactive place attachment had a stronger effect. Place satisfaction, on the other hand, was not significant for either behavioral intention. With regard to participation in tourism development, only interactive place attachment emerged as a significant predictor; it did not, however, have a significant effect on intention to leave. In contrast, place satisfaction and evaluative place attachment had a significant negative influence on leaving intention.

Reference [73], meanwhile, found that attachment depends on the type of landscape. Subjects were found to have the strongest attachment to everyday landscapes, then to natural landscapes, and last to cultural and historical landscapes. Interestingly, the results of the regression analysis showed that the two strongest ties had no significant influence on the intention to support tourism. Attachment to cultural and historical landscapes was the only tie that had a significant positive influence on intention. These findings imply that positive place experiences and connections should be emphasized to encourage residents of a destination to engage in tourism [32,73]. For example, it is important to create social interactions between residents and tourists; it is also essential to provide incentives that strengthen citizens' confidence in their competencies and skills to become valuable contributors to tourism development [32]. Additionally, destination managers should identify which kinds of cultural and historical places and characteristics are important to which groups. Once identified, these could be integrated into communication activities to motivate residents to participate [73].

Reference [72] found a significant positive influence on residents' intentions to support tourism for place identity, while place dependence had no significant effect. The work of Reference [79] supported these findings, demonstrating that, while place dependence had no significant influence on the intention to recommend short-term accommodation rentals, place affect and place identity had a significant positive influence. Nevertheless, scholars disagree about the actual role of place dependence.

While some studies find that place dependence, unlike place identity, had no significant effect on pro-tourism behavioral intentions (e.g., $[61,72,79])$, others found a significant and even stronger effect than place identity (e.g., [60,67,70,78]). Reference [67] illustrated that all three types of destination images (travel environment, natural attractions, and entertainment and events) had a positive influence on place dependence, while place iden- 
tity was only significantly positively influenced by entertainment and events. Moreover, place dependence was found to be a significant predictor of both behavioral intentions (i.e., loyalty to a destination and pro-environmental behavior at a destination), while place identity only predicted pro-environmental behavioral intentions. Their study results are in line with other findings, which revealed that destination image and place attachment are positively related (e.g., [49,50,60]. Reference [60], for example, showed that destination image - consisting of cognitive image and affective image-had a significant positive effect on both place attachment dimensions (i.e., identity and place dependence) and that place dependence mediates the influence of the destination image on revisit intention. Others indicated that place image had a positive influence on place attachment, which in turn positively influenced attitude [49], revisit intention [66], intention to recommend the destination, and intention to support tourism in the destination $[49,50]$. Interestingly, the strength of the relationship varied between residents involved in tourism and other residents of the destination. For example, the relationship between destination image and place attachment and between destination image and intention to recommend was stronger for residents who do not work in tourism than for tourism employees [50].

These results imply that the interaction of destination image and place attachment can be beneficial for promoting destinations and gaining the support of residents $[49,50,67]$. This could be achieved, for example, through further development and improvement of transportation networks and other infrastructure [50]. Attractive job and mobility offers, or sustainable green initiatives to protect the area, would also be of benefit [49]. Food quality, transportation convenience, or excursions to popular attractions represent further suitable ways that the attractiveness of a destination could be increased, and thus increase attachment and revisit intentions [60]. Moreover, destination managers should take care not to exaggerate in their marketing campaigns in order not to destroy the destination image. Any gap between tourists' expectations before a visit and their perceptions after a visit should be kept as small as possible so that they are able to build a bond with the place [66].

While attention must be paid to the destination's image, emotions and experiences also emerged from the literature as important antecedents of place attachment. Reference [31] revealed that both types of positive emotions (i.e., mild and strong feelings of pleasure) have a positive influence on the four subdimensions of place attachment (i.e., place dependence, place affect, social bonding, and place satisfaction) as well as revisit intention. In addition, place affect and social bonding were found to be significant predictors of place satisfaction and revisit intentions, with place dependence significantly influencing place affect and social bonding [31]. In a similar vein, Reference [69] illustrated a significant positive influence of personal involvement, wine involvement (i.e., wine consumers' engagement and the positive emotions associated with it), and destination emotions on place attachment. Place attachment, in turn, positively influences behavioral intention. The work of Reference [45] also demonstrated a positive influence of satisfaction, positive emotions, and negative emotions on place attachment. Nevertheless, the mediation effect of place attachment was not proven in their study.

The study by Reference [61] illustrated that memorable tourism experiences-those consisting of, for example, local culture or knowledge-positively influenced the two dimensions of place attachment: place identity and place dependence. Place identity (but not place dependence) also had a positive influence on behavioral intentions, which include revisit intention, positive word-of-mouth, and recommendation intention. Specifically, memorable tourism experiences were shown to promote place dependence, which in turn promotes place identity, which then influences behavioral intentions. Other studies included in this analysis came to similar conclusions. Positive memories of the place, a pleasant and interesting stay, and an exciting rural experience in terms of education, entertainment, escapism, aesthetics [64], experiential quality, and nostalgia [27], as well as memorable experiences tourists have of the local cuisine [71], were all found to have a positive influence on place attachment. Place attachment, meanwhile, was found to 
positively influence recommendation and revisit intentions [27,64,71]. Although the study by Reference [68] demonstrated that positive destination restaurant experiences had a positive effect on place attachment, they could not find a significant relationship between place attachment and revisit intention. Similarly, the work by Reference [86] revealed that place attachment had no significant direct effect on revisit intention. Instead, the results illustrated that place attachment positively influenced all of the constructs of the theory of planned behavior: attitude toward behavior, subjective norms, and perceived behavioral control. These three constructs were found to act as full mediators between place attachment and revisit intention [86].

Based on these results, it would be wise for destination managers to focus on evoking positive emotions in tourists in order to promote satisfaction, place attachment, and intention to recommend and to revisit $[31,45,69]$. This could be implemented, for example, through cultural events such as visiting historical buildings, offering cooking classes for local indigenous dishes, or promoting social interactions between tourists and locals. Such offers can produce emotions and memories, and thus, attachment to the place [45]. Furthermore, providing tourists with unique and memorable tourism experiences, such as sharing local recipes, information on the history of local dishes, workshops on the preparation techniques of local dishes, or knowledge offerings about local history, could increase tourists' place identification, and thus promote beneficial behavioral intentions [61,68,71]. Additionally, destination managers should highlight a destination's uniqueness and its differences from other destinations in their marketing campaigns. This can develop tourists ${ }^{\prime}$ positive emotions and unique memories, which promotes attachment to the destination and thus revisit intention [64].

Other antecedents of place attachment whose effects on behavioral intentions are mediated by place attachment include place brand credibility, celebrity attachment, environment, and benefits. Place brand credibility [48] and celebrity attachment [62] have a significant positive influence on place attachment, which in turn positively affects revisit and recommendation intention. Reference [85] examined the relationship between environment (i.e., infrastructure, atmosphere, and culture), place attachment (i.e., place identity, place dependence, social bonding, and affective attachment), and revisit intention within the framework of a stimulus-response model. They discovered that infrastructure environment and atmosphere environment were significant predictors of place attachment, while the cultural environment had no significant influence. All place attachment dimensions positively influenced revisit intention, with social bonding having the strongest effect [85]. According to Reference [77], place attachment also acts as a mediator between both desired and actually received benefits and future revisit intention.

Based on these findings, tourism managers should focus on developing benefits for tourists. A focus on recreational or experiential activities (for example, hiking in nature or fitness activities) could increase desired and received benefits for tourists [77]. In doing so, however, managers must ensure that the statements and promises remain credible. To reduce tourist uncertainty, destination managers could also provide extra information (for example, about product quality in previous years) or offer securities such as free cancellation [48]. Finally, destination managers could use well-known celebrities to promote their destination; individuals who feel connected to a celebrity will be more likely to feel an attachment to a particular place if the celebrity expresses a positive attitude toward that place [62].

Other studies considered possible moderation effects on the relationship between place attachment and other variables. Reference [65] demonstrated in their study that the relationship between place attachment and revisit intention is positively moderated by the tourist's imagination. This means that the higher the tourist's imaginative talent is, the stronger positive influence place attachment has on revisit intention. Moreover, Reference [78] showed that place dependence and place affect positively affected both desire and intention to behave in an environmentally conscious manner. The relationship between place dependence and desire, meanwhile, was negatively moderated by mass 
tourism value orientation. Mass tourists may perceive that environmentally conscious behavior on their vacation as a reduction of benefits, as this behavior may be associated with extra costs or time expenditures. At the same time, mass tourists do not feel responsible for the local environment in which they spend their vacations. The results are consistent with these theoretical considerations and demonstrate that a stronger orientation toward mass tourism leads to a weaker influence of place dependence on pro-environmental behavior. Furthermore, the research by Reference [59] indicated that nostalgia had a positive influence on place attachment and revisit intention, with place attachment mediating the positive effect. The relationship between nostalgia and place attachment was moderated by the frequency of past experiences; the more experienced the sports tourists, the weaker the positive influence of nostalgia on place attachment.

\subsection{Place Attachment as a Moderator}

In this systematic literature review, six studies used place attachment as a moderating variable.

Reference [34] examined the moderation effect of place attachment in the relationship between risk perception and intention to implement preventive behavior and between risk perception and actual preventive behavior implemented. Specifically, they investigated cases in which there was a flood risk. The study determined that risk perception had a positive influence on coping behavior in the context of both intentions and actual behavior. This relationship was moderated by higher place attachment. These findings suggest that local agencies should consider affective components in their communication and coping strategies, as these have a significant impact on resident behavior. Information about hazards and risk is particularly important in this context, as individuals should be encouraged to take preventive action to protect themselves from potential environmental hazards [34].

In the area of environmental psychology, the literature examined time donations and pro-environmental behaviors. One study found that the number of victims had a negative effect on time donations [40]. This result seems contrary to expectations, as one would expect that individuals would be more likely to donate their time when many people are involved. However, Reference [40] suggested that this may be due to the fact that, as the number of victims increases, it becomes more difficult for helpers to consider the perspectives and needs of each individual. Additionally, it is more costly to help a large group of people (compared to individuals). This effect was found to be moderated by place attachment. Accordingly, a higher place attachment led to a weakening of this negative relationship [40]. Moreover, in the work of Reference [51], openness to new experiences was shown to lead to liberal attitudes, which mediated the effect of openness on environmentally responsible behaviors. At the same time, this relationship was moderated by place identity; the relationship between liberal attitudes and pro-environmental behaviors was stronger when there was a higher place identity. Place dependence, on the other hand, had no significant influence on the relationships between openness to new experiences, liberal attitudes, and environmentally responsible behaviors [51].

These results highlight the important role of place attachment in general, as well as place identity as a subdimension of place attachment, in the development of prosocial and pro-environmental behaviors. It is therefore essential to develop appropriate strategies that strengthen people's emotional attachments to a place. In order to strengthen their intentions to help, information and communication strategies can be used to inform people, for example, about the severity of a situation and the importance of their involvement [40].

In the area of hospitality and tourism, Reference [46] analyzed the influence of perceived similarity to other guests and perceived similarity to employees on customer attitudes and loyalty. While both constructs were found to have a positive influence on attitude and loyalty, the influence of perceived similarity to other guests was stronger than that to employees. Moreover, the former relationship is moderated by place attachment, 
in the sense that higher place attachment strengthens the relationship. The results suggest that managers in the tourism sector (such as restaurants) should focus their efforts on existing customers rather than on new customers who may not fit into the similarity image of existing customers. Accordingly, measures such as personalization and loyalty programs could strengthen existing customers' attachment, and thus, their loyalty [46].

The study by Reference [63] combined the analysis of hospitality and tourism and environmental psychology by showing that festival quality has a positive and significant effect on intention to revisit, word-of-mouth recommendation, and pro-environmental behaviors. Moreover, place attachment moderated these relationships, with the direction and strength of the effect depending on the dimension of festival quality as well as the type of behavioral intention. The festival program was found to have a stronger influence on the intention to revisit the festival when place attachment is low, while other factors such as convenience, aesthetics, or information had a stronger influence when place attachment was higher. It can be concluded that visitors who have established lower (or no) place attachment are more likely to evaluate the festival based on the experience-in this case, based on the program. Managers in these areas should therefore conduct comprehensive analyses on the level of place attachment among their visitors and develop their measures based on their findings [63].

Reference [47] considered destination image with the subdimensions of conative, affective, and cognitive destination image to explain intention to revisit a place. They found that all three components had a positive influence on intention to return, and this effect was mediated by holistic image, which is a kind of imaginary conception of the individual about the entire place's image. Place attachment moderated all of the relationships except the relationship between conative destination image and intention to return. In this sense, the relationships are stronger for tourists with low place attachment than for tourists whose place attachment was already high. Destination managers should therefore analyze their target audience to determine what they value most and focus improvements and enhancements to the destination toward the tourists' desires (to promote emotional attachment) and needs (to promote functional attachment). The affective image, for example, can be promoted by focusing the program on fun, enjoyment, and relaxation. This would be particularly effective for individuals with low place attachment [47].

\subsection{Place Attachment as a Dependent Variable}

In this systematic literature review, four studies used place attachment as a dependent variable.

In the research area of environmental psychology, two of the studies in our analysis considered place attachment as a dependent variable. Both studies were by References $[39,82]$, and both investigated the relationship between place satisfaction and pro-environmental intention as well as the relationship between pro-environmental intention and place attachment. The results showed positive and significant effects for both relationships. Based on these results, managers in this area, such as destination managers or park managers, should develop strategies around strengthening place satisfaction and proenvironmental behaviors. Communication strategies about the effectiveness and benefits of pro-environmental activities can persuade people to engage in environmental activities at a particular place, which in turn will promote their place attachment. As a consequence, this can create a stronger intention to implement pro-environmental behaviors $[39,82]$.

We identified another two studies with place attachment as the dependent variable in the hospitality and tourism sector. Both of these measured place attachment as a multidimensional construct consisting of two dimensions: place identity and place dependence. Reference [57] investigated the influence of destination image on place attachment as well as place-related behavioral intentions (i.e., the intention to visit the destination again, the intention to participate in the event again, word-of-mouth recommendations for the destination, and word-of-mouth recommendations for the event). They found that the destination image dimensions (i.e., destination atmosphere, event characteristics, and attractions) had 
a significant impact on place identity and place dependence. They also found a positive and significant influence on most behavioral intentions. Only event characteristics had no significant influence on the word-of-mouth recommendations for the destination, while attractions had no significant influence on the intention to attend the event again.

In addition, Reference [58] found that service quality played a significant role in the formation of place attachment. Service quality had a positive influence on satisfaction, which in turn strengthened place identity and place dependence. Behavioral intentions such as the intention to recommend and the intention to return were also promoted.

Overall, the literature shows that attractions, atmosphere, and event characteristics, as well as service quality, are particularly important in promoting place attachment. Destination managers should focus on these attributes and, for example, issue personalized advertising packages that connect potential visitors with the specific place. It is also conceivable that they could provide information about the place, such as secrets about the destination or hidden places that are not well known [57].

\section{Conclusions and Further Research}

The results of our qualitative analysis revealed that most of the studies included in this systematic literature review provided empirical evidence of a significant relationship between place attachment and willingness to pay, loyalty, risk coping behavior, land management practices, civic engagement, pro-environmental behaviors, and pro-tourism behavior such as revisit and recommendation intentions. The relationships were either direct or indirect through various mediation variables such as self-expressiveness [7], place satisfaction [52,83], and moral norms [29,76], or attitude, subjective norms, and perceived behavioral control from the theory of planned behavior [86]. In many of the studies, place attachment was the most significant predictor of behavioral intentions (e.g., [30,44,52,55]). Overall, this systematic literature review indicates that place attachment is a particularly relevant construct through which behavioral intentions can be studied. In most cases, place attachment leads to beneficial behaviors, which is why it is indispensable for both research and practice that this psychological construct continues to be studied and integrated into decision-making processes.

The studies considered in this literature review point to several future research needs. Some of them noted that their study focused only on a specific city or country, so future studies should enable comparisons by examining similar models in other cities or countries $[7,32,39,53,62,63]$. In this context, further research should be performed to determine whether the influence of place attachment differs across cultures [63]. It would be interesting to analyze whether different views on place attachment exist from different cultural backgrounds. In addition, we recommend that experimental designs or longitudinal studies also be implemented and performed. Experiments allow researchers to manipulate one or more independent factors, and thus they may enable better identification of the influencing factors that are related to place attachment $[7,82,85]$. Some of the authors suggested that longitudinal studies, in particular, could help examine changes in place attachment and its relationships with other variables, such as behavioral intention, over time $[10,30,37,45,48,56,59,66,74,80,82]$. All of the studies included in this literature review measured place attachment at a specific point in time. However, Reference [45] suggested that measuring place attachment before and after a visit would help to determine whether and how place attachment changes as a result of a visit. Other studies recommended conducting in-depth interviews or case studies $[10,52,62,74,87]$ or combining qualitative and quantitative research (also known as mixed methods) [71,76,85].

Many of the authors saw a need for further research on the measurement of place attachment $[7,37,43,67,75]$. The conceptualization of the construct remains inconsistent, and it may be necessary to develop new items to measure place attachment [29]. Therefore, future studies should investigate whether place attachment is better measured unidimensionally or multidimensionally, and with which subdimensions and items it should be measured. For example, the literature suggests that besides the typical dimensions (i.e., 
place identity and place dependence) of place attachment, social bonding [45,54,61,74,79], place memory [45], place expectation [79], and affective attachment [72] should be included as additional dimensions of place attachment. Furthermore, Reference [45] considered place satisfaction to be a predictor of place attachment, while Reference [31], on the other hand, treated place satisfaction as a subdimension of place attachment. Other authors argued that place satisfaction is a consequence of place attachment (see, e.g., $[19,30])$. It is apparent, therefore, that further studies should investigate the relationship between place satisfaction and place attachment in more detail. Moreover, different types of place attachment are conceivable — for example, neighborhood attachment, heritage attachment, or destination attachment [41]. Future studies should be aware of the differences between the different types of place attachment and determine which attachment is most useful for which type of study.

In addition, some of the authors suggested that models examining place attachment should also include extensive sociodemographic and individual factors as control or moderating variables $[33,85]$. Reference [66], for example, recommended calculating multigroup analyses by including such variables. Various authors proposed that age [33,79], education level [33,79], length of residence, homeownership status, income [33], place of origin, occupancy [79], past experience, familiarity, satisfaction with the place [64,68,77], and frequency of past visits [64] be considered in future work.

This literature review explicitly refers to research that examines the relationship between place attachment and behavioral intention. Some of this research notes the limitation that it analyzes behavioral intention rather than actual behavior. Therefore, future studies should draw on actual behavioral data to better understand the relationship between place attachment and individual behavior $[4,30,86]$.

Finally, we must consider the COVID-19 crisis. Among the studies included in this literature review, none examined place attachment and behavioral intention in the foreground of COVID-19. Thus, it would be interesting if future studies examined the impact of COVID-19 on place attachment, as well as on the relationship between place attachment and behavioral intention [59].

Author Contributions: Conceptualization, L.D. and J.W.; Methodology, L.D.; Formal Analysis, L.D.; Data Curation, L.D.; Visualization, J.W.; Writing-Original Draft Preparation, L.D.; WritingReview and Editing, L.D. and J.W. All authors have read and agreed to the published version of the manuscript.

Funding: This research received no specific grant from any funding agency in the public, commercial, or not-for-profit sectors.

Data Availability Statement: Data sharing not applicable. No new data were created or analyzed in this study. Data sharing is not applicable to this article.

Conflicts of Interest: The authors declare no conflict of interest.

\section{References}

1. Scannell, L.; Gifford, R. The relations between natural and civic place attachment and pro-environmental behavior. J. Environ. Psychol. 2010, 30, 289-297. [CrossRef]

2. Dwyer, L.; Chen, N.; Lee, J. The role of place attachment in tourism research. J. Travel Tour. Mark. 2019, 36, 645-652. [CrossRef]

3. Domingues, R.B.; de Jesus, S.N.; Ferreira, Ó. Place attachment, risk perception, and preparedness in a population exposed to coastal hazards: A case study in Faro Beach, southern Portugal. Int. J. Disaster Risk Reduct. 2021, 60, 102288. [CrossRef]

4. Wang, K.; Tai, J.C.F.; Chang, H.-L. Influences of place attachment and social media affordances on online brand community continuance. Inf. Syst. e-Bus. Manag. 2019, 19, 459-493. [CrossRef]

5. Lewicka, M. Place attachment: How far have we come in the last 40 years? J. Environ. Psychol. 2011, 31, 207-230. [CrossRef]

6. Ramkissoon, H.; Smith, L.; Weiler, B. Testing the dimensionality of place attachment and its relationships with place satisfaction and pro-environmental behaviours: A structural equation modelling approach. Tour. Manag. 2013, 36, 552-566. [CrossRef]

7. Styvén, M.E.; Mariani, M.M.; Strandberg, C. This is my hometown! The role of place attachment, congruity, and self-expressiveness on residents' intention to share a place brand message online. J. Advert. 2020, 49, 540-556. [CrossRef]

8. Hidalgo, M.; Hernández, B. Place Attachment: Conceptual and Empirical Questions. J. Environ. Psychol. 2001, $21,273-281$. [CrossRef] 
9. Lewicka, M. What makes neighborhood different from home and city? Effects of place scale on place attachment. J. Environ. Psychol. 2010, 30, 35-51. [CrossRef]

10. Ramkissoon, H.; Smith, L.; Weiler, B. Relationships between place attachment, place satisfaction and pro-environmental behaviour in an Australian national park. J. Sustain. Tour. 2013, 21, 434-457. [CrossRef]

11. Giuliani, M.V. Theory of attachment. In Psychological Theories for Environmental Issues; Bonnes, M., Lee, T., Bonaiuto, M., Eds.; Ashgate: Aldershot, UK, 2003; pp. 137-170.

12. Brown, G.; Raymond, C.; Corcoran, J. Mapping and measuring place attachment. Appl. Geogr. 2015, 57, 42-53. [CrossRef]

13. von Wirth, T.; Grêt-Regamey, A.; Moser, C.; Stauffacher, M. Exploring the influence of perceived urban change on residents' place attachment. J. Environ. Psychol. 2016, 46, 67-82. [CrossRef]

14. Dredge, D. Place change and tourism development conflict: Evaluating public interest. Tour. Manag. 2010, 31, 104-112. [CrossRef]

15. Thomé, A.M.T.; Scavarda, L.F.; Scavarda, A.J. Conducting systematic literature review in operations management. Prod. Plan. Control. 2016, 27, 408-420. [CrossRef]

16. PRISMA. Transparent Reporting of Systematic Reviews and Meta-Analyses. 2021. Available online: http://www.prismastatement.org/ (accessed on 31 July 2021).

17. Lewicka, M. Place attachment, place identity, and place memory: Restoring the forgotten city past. J. Environ. Psychol. 2008, 28, 209-231. [CrossRef]

18. Fornara, F.; Bonaiuto, M.; Bonnes, M. Cross-Validation of Abbreviated Perceived Residential Environment Quality (PREQ) and Neighborhood Attachment (NA) Indicators. Environ. Behav. 2009, 42, 171-196. [CrossRef]

19. Prayag, G.; Ryan, C. Antecedents of tourists' loyalty to Mauritius: The role and influence of destination image, place attachment, personal involvement, and satisfaction. J. Travel Res. 2012, 51, 342-356. [CrossRef]

20. Williams, D.R.; Vaske, J.J. The measurement of place attachment: Validity and generalizability of a psychometric approach. For. Sci. 2003, 49, 830-840.

21. Williams, D.R.; Roggenbuck, J.W. Measuring place attachment: Some preliminary results. In Abstracts of the 1989 Leisure Research Symposium; McAvoy, L.H., Howard, D., Eds.; National Recreation and Park Association: Arlington, VA, USA, 1989 ; p. 32.

22. Lee, J.; Kyle, G.; Scott, D. The Mediating Effect of Place Attachment on the Relationship between Festival Satisfaction and Loyalty to the Festival Hosting Destination. J. Travel Res. 2012, 51, 754-767. [CrossRef]

23. Kyle, G.; Graefe, A.; Manning, R.; Bacon, J. Effect of Activity Involvement and Place Attachment on Recreationists' Perceptions of Setting Density. J. Leis. Res. 2004, 36, 209-231. [CrossRef]

24. Kyle, G.; Graefe, A.; Manning, R. Testing the Dimensionality of Place Attachment in Recreational Settings. Environ. Behav. 2005, 37, 153-177. [CrossRef]

25. Yuksel, A.; Yuksel, F.; Bilim, Y. Destination attachment: Effects on customer satisfaction and cognitive, affective and conative loyalty. Tour. Manag. 2010, 31, 274-284. [CrossRef]

26. Cheng, T.-M.; Wu, H.; Huang, L.-M. The influence of place attachment on the relationship between destination attractiveness and environmentally responsible behavior for island tourism in Penghu, Taiwan. J. Sustain. Tour. 2013, 21, 1166-1187. [CrossRef]

27. Tsai, C.-T.; Hsu, H.; Chen, C.-C. An examination of experiential quality, nostalgia, place attachment and behavioral intentions of hospitality customers. J. Hosp. Mark. Manag. 2020, 29, 869-885. [CrossRef]

28. Hou, G.; Chen, T.; Zhang, Q.; Wang, Y.; Yuan, Y. Getting along with danger? Place attachment, employment relationship, and protective behaviour responses. J. Conting. Crisis Manag. 2019, 27, 317-330. [CrossRef]

29. Wan, C.; Shen, G.Q.; Choi, S. The place-based approach to recycling intention: Integrating place attachment into the extended theory of planned behavior. Resour. Conserv. Recycl. 2021, 169, 105549. [CrossRef]

30. Brown, G.; Smith, A.; Assaker, G. Revisiting the host city: An empirical examination of sport involvement, place attachment, event satisfaction and spectator intentions at the London Olympics. Tour. Manag. 2016, 55, 160-172. [CrossRef]

31. Io, M.U. The relationships between positive emotions, place attachment, and place satisfaction in casino hotels. Int. J. Hosp. Tour. Adm. 2018, 19, 167-186. [CrossRef]

32. Chen, N.; Dwyer, L. Residents' Place Satisfaction and Place Attachment on Destination Brand-Building Behaviors: Conceptual and Empirical Differentiation. J. Travel Res. 2017, 57, 1026-1041. [CrossRef]

33. Widya, A.T.; Kusuma, H.E.; Lubis, R.A. The Correlational Relationship between Residential Satisfaction, Place Attachment, and Intention to Move: A Preliminary Study in Belawan, Medan. J. Reg. City Plan. 2019, 30, 191. [CrossRef]

34. De Dominicis, S.; Fornara, F.; Cancellieri, U.G.; Twigger-Ross, C.; Bonaiuto, M. We are at risk, and so what? Place attachment, environmental risk perceptions and preventive coping behaviours. J. Environ. Psychol. 2015, 43, 66-78. [CrossRef]

35. Ariccio, S.; Petruccelli, I.; Cancellieri, U.G.; Quintana, C.; Villagra, P.; Bonaiuto, M. Loving, leaving, living: Evacuation site place attachment predicts natural hazard coping behavior. J. Environ. Psychol. 2020, 70, 101431. [CrossRef]

36. Leahy, J.; Lyons, P. Place Attachment and Concern in Relation to Family Forest Landowner Behavior. Forests 2021, 12, 295. [CrossRef]

37. Simões, F.; Rocha, R.; Mateus, C. Beyond the prophecy success: How place attachment and future time perspective shape rural university students intentions of returning to small islands. J. Youth Stud. 2019, 23, 909-925. [CrossRef]

38. Stefaniak, A.; Bilewicz, M.; Lewicka, M. The merits of teaching local history: Increased place attachment enhances civic engagement and social trust. J. Environ. Psychol. 2017, 51, 217-225. [CrossRef] 
39. Ramkissoon, H.; Mavondo, F.T. Proenvironmental Behavior: Critical Link Between Satisfaction and Place Attachment in Australia and Canada. Tour. Anal. 2017, 22, 59-73. [CrossRef]

40. Kim, M.; Kim, J. The role of place attachment in diminishing compassion fade in the time donation context. J. Environ. Psychol. 2020, 70, 101462. [CrossRef]

41. Nian, S.; Zhang, H.; Mao, L.; Zhao, W.; Zhang, H.; Lu, Y.; Zhang, Y.; Xu, Y. How outstanding universal value, service quality and place attachment influences tourist intention towards world heritage conservation: A case study of Mount Sanqingshan National Park, China. Sustainability 2019, 11, 3321. [CrossRef]

42. Yu, T.-K.; Chang, Y.-J.; Chang, I.-C. A pro-environmental behavior model for investigating the roles of social norm, risk perception, and place attachment on adaptation strategies of climate change. Environ. Sci. Pollut. Res. 2019, 26, 25178-25189. [CrossRef]

43. Culha, O. The effect of food festival quality on place attachment and destination recommendation intention through festival experience and festival satisfaction: The case of the Didim International Olive Festival. J. Conv. Event Tour. 2020, 21, 387-416. [CrossRef]

44. Nghiêm-Phú, B.; Kiều, T.H.; Hoàng, T.T.T. Tourists' satisfaction with and intentions toward a nature-themed festival: The contribution of destination attributes, festival events, place attachment and life satisfaction. J. Conv. Event Tour. 2021, 22, 221-241. [CrossRef]

45. Hosany, S.; Prayag, G.; Van Der Veen, R.; Huang, S.; Deesilatham, S. Mediating effects of place attachment and satisfaction on the relationship between tourists' emotions and intention to recommend. J. Travel Res. 2017, 56, 1079-1093. [CrossRef]

46. Hanks, L.; Zhang, L.; Line, N. Perceived similarity in third places: Understanding the effect of place attachment. Int. J. Hosp. Manag. 2020, 86, 102455. [CrossRef]

47. Stylos, N.; Bellou, V.; Andronikidis, A.; Vassiliadis, C.A. Linking the dots among destination images, place attachment, and revisit intentions: A study among British and Russian tourists. Tour. Manag. 2017, 60, 15-29. [CrossRef]

48. Reitsamer, B.F.; Brunner-Sperdin, A. It's all about the brand: Place brand credibility, place attachment, and consumer loyalty. J. Brand Manag. 2021, 28, 291-301. [CrossRef]

49. Shen, K.; Geng, C.; Su, X. Antecedents of residents' pro-tourism behavioral intention: Place image, place attachment, and attitude. Front. Psychol. 2019, 10, 2349. [CrossRef]

50. Stylidis, D. Using Destination Image and Place Attachment to Explore Support for Tourism Development: The Case of Tourism Versus Non-tourism Employees in EILAT. J. Hosp. Tour. Res. 2020, 44, 951-973. [CrossRef]

51. Snider, A.G.; Luo, S.; Fusco, E. Predicting college students' environmentally responsible behavior from personality, political attitudes, and place attachment: A synergistic model. J. Environ. Stud. Sci. 2018, 8, 290-299. [CrossRef]

52. Lee, D.; Lee, J.H. A structural relationship between place attachment and intention to conserve landscapes-A case study of Harz National Park in Germany. J. Mt. Sci. 2017, 14, 998-1007. [CrossRef]

53. Su, W.-S.; Hsu, C.-C.; Huang, C.-H.; Chang, L.-F. Setting Attributes and Revisit Intention as Mediated by Place Attachment. Soc. Behav. Pers. Int. J. 2018, 46, 1967-1981. [CrossRef]

54. Zhang, C.X.; Fong, L.H.N.; Li, S. Co-creation experience and place attachment: Festival evaluation. Int. J. Hosp. Manag. 2019, 81, 193-204. [CrossRef]

55. Neuvonen, M.; Pouta, E.; Sievänen, T. Intention to revisit a national park and its vicinity: Effect of place attachment and quality perceptions. Int. J. Sociol. 2010, 40, 51-70. [CrossRef]

56. Uesugi, A.; Kudo, Y. The relationship between outdoor sport participants' place attachment and pro-environment behaviour in natural areas of Japan for developing sustainable outdoor sport tourism. Eur. J. Sport Soc. 2020, 17, 162-179. [CrossRef]

57. Kaplanidou, K.; Jordan, J.S.; Funk, D.; Ridinger, L.L. Recurring Sport Events and Destination Image Perceptions: Impact on Active Sport Tourist Behavioral Intentions and Place Attachment. J. Sport Manag. 2012, 26, 237-248. [CrossRef]

58. Su, H.-J.; Cheng, K.-F.; Huang, H.-H. Empirical study of destination loyalty and its antecedent: The perspective of place attachment. Serv. Ind. J. 2011, 31, 2721-2739. [CrossRef]

59. Cho, H. How nostalgia forges place attachment and revisit intention: A moderated mediation model. Mark. Intell. Plan. 2021, 39, 856-870. [CrossRef]

60. Song, H.-M.; Kim, K.-S.; Yim, B.H. The mediating effect of place attachment on the relationship between golf tourism destination image and revisit intention. Asia Pac. J. Tour. Res. 2017, 22, 1182-1193. [CrossRef]

61. Tsai, C.-T. Memorable Tourist Experiences and Place Attachment When Consuming Local Food. Int. J. Tour. Res. 2016, 18, 536-548. [CrossRef]

62. Wong, J.-Y.; Lai, T.-C. Celebrity Attachment and Behavioral Intentions: The Mediating Role of Place Attachment. Int. J. Tour. Res. 2013, 17, 161-170. [CrossRef]

63. Kim, S.; Lee, Y.-K.; Lee, C.-K. The moderating effect of place attachment on the relationship between festival quality and behavioral intentions. Asia Pac. J. Tour. Res. 2017, 22, 49-63. [CrossRef]

64. Loureiro, S.M.C. The role of the rural tourism experience economy in place attachment and behavioral intentions. Int. J. Hosp. Manag. 2014, 40, 1-9. [CrossRef]

65. Hosany, S.; Buzova, D.; Sanz-Blas, S. The Influence of Place Attachment, Ad-Evoked Positive Affect, and Motivation on Intention to Visit: Imagination Proclivity as a Moderator. J. Travel Res. 2020, 59, 477-495. [CrossRef]

66. Jin, M.-L.; Choi, Y.; Lee, C.-K.; Ahmad, M. Effects of Place Attachment and Image on Revisit Intention in an Ecotourism Destination: Using an Extended Model of Goal-Directed Behavior. Sustainability 2020, 12, 7831. [CrossRef] 
67. Lee, Y.K.; Pei, F.; Ryu, K.S.; Choi, S. Why the tripartite relationship of place attachment, loyalty, and pro-environmental behaviour matter? Asia Pac. J. Tour. Res. 2019, 24, 250-267. [CrossRef]

68. Mohamed, M.E.; Kim, D.C.; Lehto, X.; Behnke, C.A. Destination restaurants, place attachment, and future destination patronization. J. Vacat. Mark. 2021. [CrossRef]

69. Santos, V.R.; Ramos, P.; Almeida, N. The relationship between involvement, destination emotions and place attachment in the Porto wine cellars. Int. J. Wine Bus. Res. 2017, 29, 401-415. [CrossRef]

70. Shang, W.; Qiao, G.; Chen, N. Tourist experience of slow tourism: From authenticity to place attachment-A mixed-method study based on the case of slow city in China. Asia Pac. J. Tour. Res. 2020, 25, 170-188. [CrossRef]

71. Sthapit, E.; Björk, P.; Coudounaris, D.N. Emotions elicited by local food consumption, memories, place attachment and behavioural intentions. Anatolia 2017, 28, 363-380. [CrossRef]

72. Yuan, Q.; Song, H.; Chen, N.; Shang, W. Roles of Tourism Involvement and Place Attachment in Determining Residents' Attitudes Toward Industrial Heritage Tourism in a Resource-Exhausted City in China. Sustainability 2019, 11, 5151. [CrossRef]

73. Zhang, H.; Lei, S.L. Effects of place attachment on participation intentions for local tourism development. Sustain. Tour. 2010 139, 501-509. [CrossRef]

74. Halpenny, E.A. Pro-environmental behaviours and park visitors: The effect of place attachment. J. Environ. Psychol. 2010, 30, 409-421. [CrossRef]

75. López-Mosquera, N.; Sánchez, M. Direct and indirect effects of received benefits and place attachment in willingness to pay and loyalty in suburban natural areas. J. Environ. Psychol. 2013, 34, 27-35. [CrossRef]

76. Valizadeh, N.; Bijani, M.; Karimi, H.; Naeimi, A.; Hayati, D.; Azadi, H. The effects of farmers' place attachment and identity on water conservation moral norms and intention. Water Res. 2020, 185, 116131. [CrossRef] [PubMed]

77. Kil, N.; Holland, S.M.; Stein, T.V.; Ko, Y.J. Place attachment as a mediator of the relationship between nature-based recreation benefits and future visit intentions. J. Sustain. Tour. 2012, 20, 603-626. [CrossRef]

78. Qu, Y.; Xu, F.; Lyu, X. Motivational place attachment dimensions and the pro-environmental behaviour intention of mass tourists: A moderated mediation model. Curr. Issues Tour. 2017, 22, 197-217. [CrossRef]

79. Xu, X.; Gursoy, D. Exploring the relationship between servicescape, place attachment, and intention to recommend accommodations marketed through sharing economy platforms. J. Travel Tour. Mark. 2020, 37, 429-446. [CrossRef]

80. Lai, P.-H.; Kreuter, U.P. Examining the direct and indirect effects of environmental change and place attachment on land management decisions in the Hill Country of Texas, USA. Landsc. Urban Plan. 2012, 104, 320-328. [CrossRef]

81. Tonge, J.; Ryan, M.M.; Moore, S.A.; Beckley, L.E.; Pearce, J. The Effect of Place Attachment on Pro-environment Behavioral Intentions of Visitors to Coastal Natural Area Tourist Destinations. J. Travel Res. 2014, 54, 730-743. [CrossRef]

82. Ramkissoon, H.; Mavondo, F.T. The satisfaction-place attachment relationship: Potential mediators and moderators. J. Bus. Res. 2015, 68, 2593-2602. [CrossRef]

83. Chow, A.S.; Ma, A.T.; Wong, G.K.; Lam, T.W.; Cheung, L.T. The Impacts of Place Attachment on Environmentally Responsible Behavioral Intention and Satisfaction of Chinese Nature-Based Tourists. Sustainability 2019, 11, 5585. [CrossRef]

84. Ramkissoon, H.; Weiler, B.; Smith, L. Place attachment, place satisfaction and pro-environmental behaviour: A comparative assessment of multiple regression and structural equation modelling. J. Policy Res. Tour. Leis. Events 2013, 5, 215-232. [CrossRef]

85. Isa, S.M.; Ariyanto, H.H.; Kiumarsi, S. The effect of place attachment on visitors' revisit intentions: Evidence from Batam. Tour. Geogr. 2019, 22, 51-82. [CrossRef]

86. Han, J.H.; Kim, J.S.; Lee, C.K.; Kim, N. Role of place attachment dimensions in tourists' decision-making process in Cittáslow. J. Dest. Market. Manag. 2019, 11, 108-119. [CrossRef]

87. Shaykh-Baygloo, R. A multifaceted study of place attachment and its influences on civic involvement and place loyalty in Baharestan new town, Iran. Cities 2019, 96, 102473. [CrossRef]

88. Twigger-Ross, C.L.; Breakwell, G.M. Relating risk experience, venturesomeness and risk perception. J. Risk Res. 1999, 2, 73-83. [CrossRef]

89. Luís, S.; Pinho, L.; Lima, M.L.; Roseta-Palma, C.; Martins, F.C.; De Almeida, A.B. Is it all about awareness? The normalization of coastal risk. J. Risk Res. 2016, 19, 810-826. [CrossRef]

90. Michel-Guillou, E.; Krien, N.; Meur-Ferec, C. Inhabitants of coastal municipalities facing coastal risks: Understanding the desire to stay. Pap. Soc. Represent. 2016, 2521, 8-9.

91. Bricker, K.S.; Kerstetter, D.L. Level of specialization and place attachment: An exploratory study of whitewater recreationists. Leis. Sci. 2000, 22, 233-257.

92. Kyle, G.T.; Absher, J.D.; Graefe, A.R. The Moderating Role of Place Attachment on the Relationship between Attitudes toward Fees and Spending Preferences. Leis. Sci. 2003, 25, 33-50. [CrossRef] 